\title{
KEMAMPUAN ANALOGI MATEMATIS MAHASISWA PADA MATA KULIAH KALKULUS DIFFERENSIAL
}

\author{
Fitrianto Eko Subekti ${ }^{1}$, Gunawan ${ }^{2}$ \\ ${ }^{1}$ Universitas Muhammadiyah Purwokerto \\ efitrians@ymail.com \\ ${ }^{2}$ Universitas Muhammadiyah Purwokerto \\ gun.oge@gmail.com
}

\begin{abstract}
ABSTRAK
Penelitian ini bertujuan untuk menggambarkan kemampuan analogi matematis mahasiswa pada mata kuliah kalkulus differensial. Penelitian ini menggunakan metode penelitian kualitatif dengan menggunakan model Miles and Huberman yang meliputi reduksi data, penyajian data, dan kesimpulan. Teknik pengambilan sampel menggunakan teknik purposive sampling. Mahasiswa dikelompokkan ke dalam tiga kategori berdasarkan hasil belajar yaitu rendah, sedang, dan tinggi. Dari kategori rendah mayoritas belum memahami konsep dan keserupaan konsep yang digunakan untuk menyelesaikan persoalan, baik masalah sumber maupun masalah target. Untuk kategori sedang, mayoritas sudah mampu memahami konsep dan keserupaan konsep yang digunakan, hanya saja belum mampu mengaplikasikannya untuk menyelesaikan persoalan. Sedangkan untuk kategori tinggi, mayoritas sudah memahami konsep, keserupaan konsep yang digunakan, dan mampu mengaplikasikannya untuk menyelesaikan masalah sumber dan target.
\end{abstract}

Kata Kunci: Analogi Matematis, Pemahaman Konsep, Kalkulus Differensial

\begin{abstract}
This research aims to describe the students' mathematical analogy ability in differential calculus course. This research uses qualitative research methods of Miles and Huberman model that includes the reduction of data, data presentation, and conclusion. Sampling was done by purposive sampling technique. This research involves students from various learning outcome categories: low, medium, and high. The majority of low students have not understood the concept used to solve the problems related to resources and target. The majority of medium students are able to understand the concept, but they are not able to apply the concept in problem solving. However, the majority of high students are able to understand the concept in real world problem. Moreover, this group is able to apply in problem solving related to resources and target.
\end{abstract}

Key words: Mathematical Analogy, Conceptual Understanding, Differential Calculus

Format Sitasi: Subekti, F. E. \& Gunawan. (2018). Kemampuan Analogi Matematis Mahasiswa pada Mata Kuliah Kalkulus Differensial. KALAMATIKA Jurnal Pendidikan Matematika, 3(2), 223-238. 
Penyerahan Naskah: 12 Maret 2018 || Revisi: 28 September 2018 || Diterima: 29 September 2018

\section{PENDAHULUAN}

Mahasiswa Pendidikan Matematika Universitas Muhammadiyah Purwokerto merupakan mahasiswa yang dipersiapkan untuk menjadi calon guru di Sekolah Menengah, baik sekolah menengah pertama maupun menengah atas. Mereka dibekali berbagai materi yang menjadi dasar untuk mengajar matematika di sekolah menengah. Salah satu materi yang diajarkan sebagai dasar untuk mengajar pada jenjang sekolah menengah atas adalah materi limit, fungsi dan turunan. Materi ini diajarkan pada mata kuliah kalkulus differensial. Secara khusus mata kuliah ini membekali mahasiswa untuk dapat memahami dan menyelesaikan masalah yang terkait dengan sistem bilangan, fungsi dan grafiknya, limit dan fungsi kontinu, dan turunan. Selain itu mata kuliah kalkulus differensial merupakan mata kuliah yang mendasari beberapa mata kuliah yang lain, diantaranya: kalkulus integral, kalkulus multivariabel, kalkulus vektor, persamaan differensial biasa, dsb.

Salah satu kemampuan yang mendasari mata kuliah tersebut adalah kemampuan penalaran matematis. Penalaran merupakan proses berpikir dalam menarik kesimpulan untuk menghasilkan pengetahuan yang benar (Suriasumantri, 1999). Penalaran juga dikatakan sebagai tindakan menggunakan akal untuk mendapatkan kesimpulan dari pernyataan tertentu (Mofidi, 2012). Sejalan dengan pernyataan tersebut, Santrock (2008) menyatakan bahwa penalaran merupakan pemikiran menggunakan logika baik induksi maupun deduksi untuk mendapatkan suatu kesimpulan. Sedangkan Penalaran matematis merupakan kemampuan berpikir untuk mengetahui, mengenali, menyatakan hubungan antara simbol dengan konsepkonsep abstrak, dan menggunakan pola serta hubungan antara objek, simbol dan konsep (English, 1993).

Penalaran deduktif merupakan proses penalaran dari keadaan umum ke keadaan khusus. Penalaran ini terjadi apabila dalam proses berpikir tersebut dihasilkan kesimpulan atau pernyataan baru dari fakta-fakta atau pernyataan yang dianggap benar menggunakan logika (Shadiq, 2009). Selanjutnya Shadiq, (2009) menyatakan bahwa penalaran induktif merupakan proses penalaran dari keadaan khusus ke keadaan umum. Penalaran induktif terjadi ketika proses berpikr kesimpulan yang bersifat umum. Salah satu bentuk penalaran induktif adalah penalaran analogi (Santrock, 2008). 
Kemampuan analogi matematis menjadikan mahasiswa tidak hanya mampu menggunakan rumus dalam menyelesaikan masalah, tetapi juga mampu menggunakan rumus tersebut untuk menyelesaikan masalah serupa. Kemampuan analogi menjadikan mahasiswa menggunakan pengalaman yang sudah dimiliki untuk menyelesaikan permasalahan yang baru.

Kemampuan analogi merupakan cara yang digunakan untuk menunjukkan penyelesaian dua permasalahan dengan cara serupa (Meagher, 2006) maupun melihat kesamaan struktur yang dimiliki oleh kedua permasalahan tersebut (English, 1993) di antara hal-hal yang berbeda (Santrock, 2008). Hal ini sejalan dengan pernyataan dari Keane (1996) yang menyatakan bahwa kemampuan analogi digunakan untuk memecahkan masalah kedua dengan melihat kesamaan struktur masalah pertama. Dengan kata lain penalaran analogi digunakan untuk melihat persamaan pola dari dua permasalahan, sehingga kedua permasalahan tersebut dapat terselesaikan.

Ada tiga unsur dalam penalaran analogi, yaitu: 1) masalah sumber; 2) masalah target; dan 3) kesamaan struktur (Sudarma, 2013). Adapun tiga unsur tersebut dijabarkan sebagai berikut: 1) Masalah sumber merupakan masalah dasar, dalam penyelesainnya membutuhkan pengalaman-pengalaman dalam menyelesaikan permasalahan yang diberikan; 2) Masalah target merupakan permasalahan yang menjadi tujuan utama, dimana permasalahan tersebut dapat diselesaikan apabila sudah ditemukan kesamaan pola dari dua masalah tersebut atau menggunakan penyelesaian masalah sumber sebagai dasar dalam menyelesaikan masalah target; dan 3) Kesamaan struktur merupakan salah satu hal penting dalam penalaran analogi, kesamaan struktur menjadikan penyelesaian masalah target menjadi lebih mudah (English, 1993). Hal ini sejalan dengan pernyataan Gentner (2006) yang menyatakan bahwa kesamaan struktur dari dua permasalahan lebih penting dari pada perbandingan.

Jika mahasiswa tidak mampu dalam beranalogi, maka berakibat dia akan kesulitan jika diberikan permasalahan-permasalahan yang menuntut pengalaman-pengalaman atau dasar yang sudah dimiliki dalam menyelesaikan masalah. Hal ini berakibat, mahasiswa hanya dapat menyelesaikan permasalahan-permasalahan yang menggunakan rumus dasar, tetapi kesulitan jika penyelesaian masalah membutuhkan pengembangan rumus yang digunakan.

Berdasarkan hasil observasi dalam pembelajaran kalkulus differensial, ditemukan beberapa permasalahan, seperti: 1) mahasiswa mampu menyelesaikan permasalahan yang menggunakan rumus dasar, tetapi kesulitan ketika persoalan tersebut membutuhkan rumus 
yang pengembangan; 2) mahasiswa terlihat ragu-ragu untuk menggunakan pengalaman yang dimiliki untuk menyelesaikan permasalahan yang baru. Hal-hal tersebut merupakan permasalahan yang berkaitan dengan kemampuan analogi matematis. Dengan ketidakmampuan dalam mengunakan pengalaman yang sudah dimiliki untuk menyelesaikan masalah baru berakibat, mereka akan kesulitan dalam menyelesaikan permasalahanpermasalahan yang kompleks.

Dengan adanya beberapa permasalahan tersebut, perlu digali lebih dalam tentang kemampuan mereka dalam beranalogi. Jika kemampuan-kemampuan mahasiswa tersebut semakin baik, maka diharapkan pembelajaran kalkulus differensial akan lebih mudah dipahami oleh mahasiswa.

\section{METODE PENELITIAN}

Metode penelitian yang digunakan oleh peneliti adalah metode penelitian deskriptif dengan pendekatan kualitatif. Peneliti ingin memberikan gambaran yang lebih mendalam mengenai kemampuan analogi matematis mahasiswa dalam memecahkan masalah pada mata kuliah kalkulus differensial. Prosedur penelitian ini meliputi tiga tahapan utama yaitu: tahap persiapan, pelaksanaan, dan analisis data. Hal-hal yang dilakukan pada saat persiapan diantaranya: menentukan sampel penelitian menggunakan teknik purposive sampling, penyusunan soal dan pedoman wawancara. Dalam hal ini pengambilan sampel berdasarkan hasil UTS mahasiswa. Diambil masing-masing mahasiswa dari setiap kategori, yaitu kategori rendah, sedang dan tinggi. Pada saat pelaksanaan, dilakukan pengambilan data tentang kemampuan analogi matematis mahasiswa dengan cara tes dan wawancara. Teknik analisis data yang digunakan peneliti menggunakan teknik Miles dan Hubberman (Sugiyono, 2012), yang meliputi: reduksi data; penyajian data; dan penyimpulan data. Mereduksi berarti merangkum, memilih hal-hal pokok, dan memfokuskan pada masalah yang ingin dianalisis. Dengan reduksi data, maka gambaran kemampuan analogi matematis akan semakin jelas. Setelah data direduksi, kemudian data disajikan. Penyajian data dilakukan dalam bentuk uraian singkat, bagan, atau hubungan antar kategori, Dengan penyajian data, maka akan memudahkan memahami apa yang terjadi, dan dapat digunakan untuk merencanakan apa yang akan dilakukan selanjutnya. Langkah selanjutnya adalah penarikan kesimpulan. Hasil 
kesimpulan berupa gambaran tentang kemampuan penalaran analogi dari mahasiswa yang mengambil mata kuliah kalkulus differensial.

\section{HASIL DAN PEMBAHASAN}

Berdasarkan nilai UTS mata kuliah kalkulus differensial, mahasiswa dikelompokkan menjadi tiga kelompok, yaitu: kelompok tinggi, sedang, dan rendah. Dari masing-masing kelompok tersebut, dipilih tiga mahasiswa sebagai responden untuk digali lebih dalam kemampuan analogi matematisnya. Adapun Mahasiswa yang dipilih sebagai responden dapat dilihat pada tabel 1 berikut.

Tabel 1. Daftar Responden

\begin{tabular}{lc}
\hline \multicolumn{1}{c}{ Kelompok } & Responden \\
\hline Rendah & RA, BA, dan AR \\
Sedang & FF, PD, dan MS \\
Tinggi & FB, OM, dan DS \\
\hline
\end{tabular}

Setelah dipilih 9 responden, kemudian dilakukan tes dan wawancara terkait kemampuan analogi matematis dari masing-masing responden tersebut. Soal terdiri atas 4 butir soal, dimana butir soal nomor satu merupakan masalah sumber yang menjadi dasar untuk menyelesaikan butir soal nomor 2. Sedangkan butir soal nomor 3 memiliki kesamaan konsep/ struktur dengan butir soal nomor 4. Berikut soal tes kemampuan analogi matematis yang diberikan kepada 9 responden pada gambar 1.

1. Diberikan $f(x)$ sebagai berikut:

$$
\begin{aligned}
& f(x)=\left\{\begin{array}{c}
-3 x, \text { jikax }<0 \\
x^{2}+1, \text { jikax }=0 \\
2 x-x^{2}, \text { jikax }>0 .
\end{array}\right. \\
& \text { Tentukan } \lim _{\Delta x \rightarrow 0} \frac{f(0+\Delta x)-f(0)}{\Delta x}
\end{aligned}
$$

2. Berdasarkan nomor $1, f$ terdifferensial di $x=0$ ?

3. Tentukan turunan fungsi dari $y=\frac{1}{4 x^{2}-3 x+9}$.

4. Tentukan $\frac{d y}{d x}$ jika $y=\frac{x^{2}-x+1}{x^{2}+1}$.

Gambar 1. Soal Tes Kemampuan Analogi Matematis 
Adapun gambaran kemampuan analogi matematis dari setiap responden sebagai berikut.

1. Responden 1 (RA)
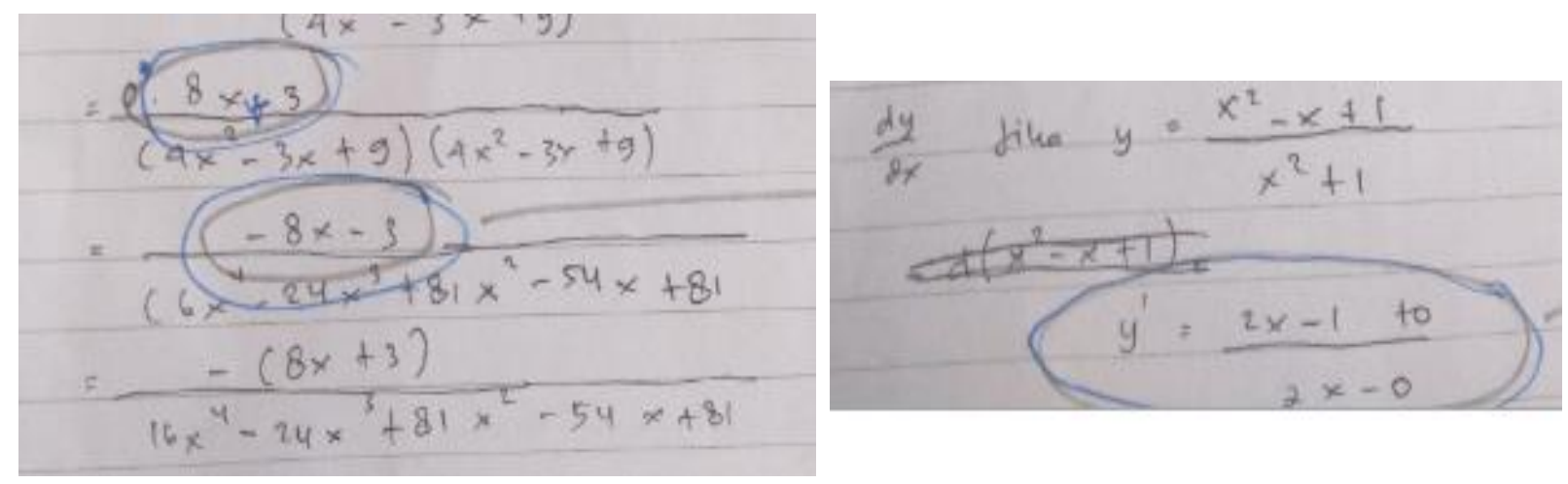

Gambar 2. Jawaban Responden 1 untuk Butir Soal Nomor 3 dan 4.

Pada gambar 2 terlihat bahwa untuk menyelesaikan persoalan nomor 1, responden terlebih dahulu menentukan limit kiri dan limit kanan. Hanya saja ia tidak meneruskan jawabannya. Untuk persoalan nomor 2, ia tidak menjawab. Sedangkan untuk persoalan nomor 3 dan 4 seperti pada gambar 2 di atas ia menuliskan terlebih dahulu fungsi $u(x), v(x), u^{\prime}(x)$, dan $v^{\prime}(x)$. Setelah itu, menggunakan rumus turunan fungsi pembagian. Pada proses jawaban, terdapat kesalahan dalam menghitung, yaitu: menghitung nilai $[0 .(8 x-3)]$. Ia menuliskan $[0 .(8 x-3)]=-8 x-3$. Jawaban tersebut keliru, seharusnya adalah $[0 .(8 x-3)]=0$. Akibatnya, jawaban yang dituliskan menjadi salah. Sedangkan untuk jawaban butir soal nomor 4, responden keliru menentukan turunan fungsi pembagian. Aturan yang digunakan tidak jelas. Sehingga, jawaban pada soal nomor 4 masih salah.

Hal ini diperkuat berdasarkan hasil wawancara, untuk butir soal nomor 1, ia tidak dapat mengerjakan soal karena merasa bingung bagaimana cara mengerjakannya dan tidak mengetahui konsep apa yang digunakan. Ia juga tidak dapat menjelaskan hubungan antara butir soal nomor 1 dan 2. Sedangkan untuk butir soal nomor 3, ia sudah dapat menjelaskan konsep yang digunakan tetapi merasa tidak yakin dengan jawabannya. Sedangkan untuk butir soal nomor 4, ia tidak dapat memahami soal, tidak dapat menjelaskan aturan yang digunakan, dan tidak dapat menjelaskan hubungan antara butir soal nomor 3 dan 4. 
2. Responden 2 (BA)

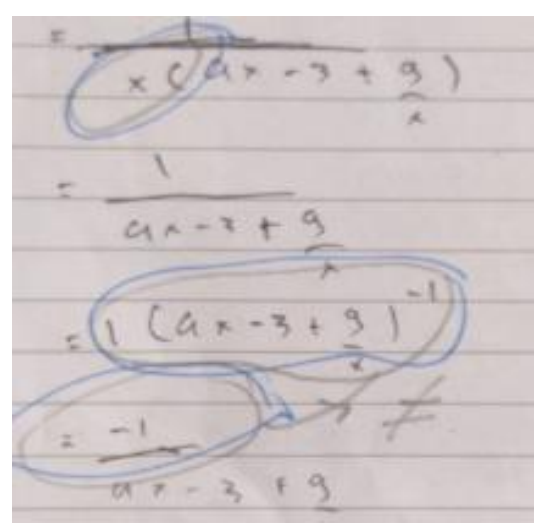

Gambar 3. Jawaban Responden 2 pada Butir Soal Nomor 3

Untuk jawaban butir soal nomor 1, responden masih salah dalam menuliskan definisi turunan fungsi di titik 0. Ia menuliskan $\lim _{\Delta x \rightarrow 0} \frac{f(0+\Delta-3)-f(0)}{\Delta-3}$. Rumus tersebut tidak dapat digunakan untuk menentukan turunan fungsi $f$ di suatu titik. Kemudian, pada akhir jawaban menuliskan, ia menuliskan $\lim _{\Delta 0 \rightarrow 0} \frac{f(0)-f(0)}{\Delta 0}=0$. Jawaban tersebut salah karena tidak ada istilah $\Delta 0$. Untuk butir soal nomor 2, ia tidak menjawab. Untuk butir soal nomor 3, seperti pada gambar 3, responden langsung menuliskan $y=\frac{1}{x\left(4 x-3+\frac{9}{x}\right)}$. Di bagian akhir, ia menuliskan $\frac{-1}{4 x-3+\frac{9}{x}}=-\frac{1}{4}$. Proses tersebut salah, sehingga, jawaban untuk butir soal nomor 3 menjadi salah. Sedangkan, untuk jawaban butir soal nomor 4 hampir sama dengan jawaban butir soal nomor 3. Aturan pengerjaan yang digunakan juga sama. Karena aturan yang digunakan sama dan jawaban butir soal nomor 3 salah, maka jawaban butir nomor 4 juga salah.

Berdasarkan hasil wawancara, ia tidak dapat memahami pertanyaan dan tidak mengetahui konsep yang digunakan untuk menjawab butir soal nomor 1. Hal ini berakibat responden tidak dapat mengerjakan butir soal nomor 2. Begitu juga untuk butir soal nomor 3 dan 4, ia tidak dapat menjelaskan konsep yang digunakan, sehingga jawabannya menjadi salah. 
3. Responden $3(\mathrm{AR})$

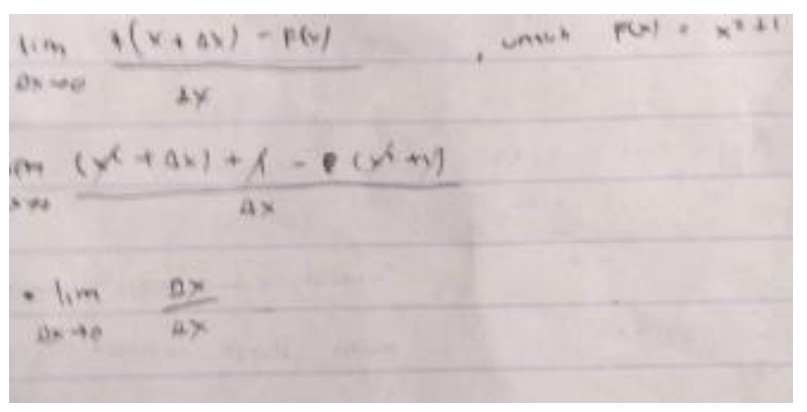

Gambar 4. Jawaban Responden 3 untuk Butir Soal Nomor 1

Berdasarkan jawaban butir soal nomor 1 pada gambar 4 di atas, responden masih keliru dalam menuliskan definisi turunan fungsi pembagian dan jawaban dituliskan tidak selesai. Untuk jawaban butir soal nomor 2, ia menggunakan aturan fungsi kontinu, akan tetapi jawabannya masih terdapat kesalahan. Ia beranggapan jika $f$ fungsi kontinu, maka $f$ terdifferensial. Padahal aturan tersebut tidak dapat dijadikan pedoman, karena ada fungsi kontinu yang tidak terdifferensial. Untuk jawaban butir soal nomor 3, terlebih dahulu ia menentukan fungsi $\mathrm{u}(\mathrm{x}), \mathrm{v}(\mathrm{x}), u^{\prime}(x)$, dan $v^{\prime}(x)$ dan menggunakan aturan turunan pembagian untuk menyelesaikan persoalan tersebut. Sedangkan, untuk butir soal nomor 4, ia juga sudah dapat menyelesaikan persoalan tersebut dengan benar dengan menuliskan terlebih dahulu fungsi yang dibutuhkan.

Hal ini diperkuat berdasarkan hasil wawancara, bahwa responden tidak dapat menerapkan konsep yang digunakan pada butir soal nomor 1 dan ia mengaku ragu- ragu dalam mengerjakan butir soal nomor 1 dan 2. Ia tidak yakin dengan pengetahuan konsep yang dimilikinya padahal konsepnya benar. Sedangkan untuk butir soal nomor 3 dan 4, ia dapat menjelaskan konsep yang digunakan yaitu aturan sifat operasi pembagian turunan.

4. Responden 4 (FF)
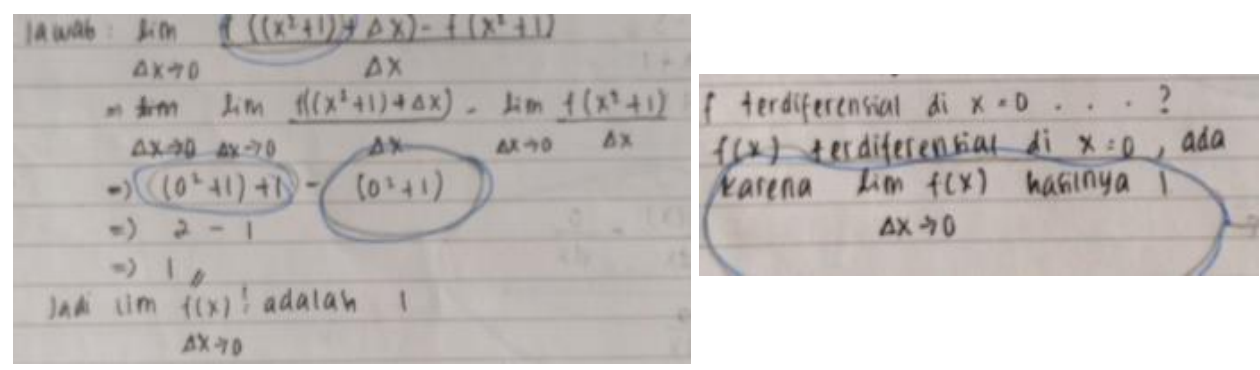

Gambar 5. Jawaban Responden pada Soal Nomor 1 dan 2 
Berdasarkan jawaban responden untuk butir soal nomor 1 seperti pada gambar 5 di atas, ia menggunakan definisi turunan fungsi di titik 0 , akan tetapi dalam menuliskan definisi tersebut masih terdapat kesalahan. Ia menuliskan $f\left(\left(x^{2}+1\right)+\Delta x\right)$, yang seharusnya $f(0+\Delta x)$. Selain itu pada proses penyelesaian juga terdapat kesalahan, yaitu langsung menuliskan $\left(0^{2}+1\right)+1$ tanpa disertai penjelasan prosesnya. Untuk butir soal nomor 2 , ia memberikan alasan bahwa fungsi $f$ terdifferensial di titik 0 karena $\lim _{\Delta x \rightarrow 0} f(x)$ hasilnya 1 . Alasan tersebut tidak benar karena tidak ada hubungan antara turunan fungsi dengan $\lim _{\Delta x \rightarrow 0} f(x)$. Untuk butir soal nomor 3, ia terlebih dahulu menuliskan fungsi yang digunakan, yaitu $\mathrm{u}(\mathrm{x}), \mathrm{v}(\mathrm{x}), u^{\prime}(x)$, dan $v^{\prime}(x)$. Setelah itu, ia menuliskan rumus turunan fungsi untuk pembagian. Hanya saja dalam menuliskan rumus masih terdapat kesalahan. Ia menuliskan $u^{\prime}(x) \cdot v(x)-u(x) \cdot v^{\prime}(x)$, yang seharusnya adalah $\frac{u^{\prime}(x) \cdot v(x)-u(x) \cdot v^{\prime}(x)}{(v(x))^{2}}$. Sedangkan untuk butir soal nomor 4, ia menuliskan rumus $y^{\prime}=\frac{\frac{d\left(x^{2}\right)}{d x}-\frac{d(x)}{d x}-\frac{0}{d x}}{\frac{d\left(x^{2}\right)}{d x}-\frac{0}{d x}}$. Rumus tersebut salah karena tidak ada aturan tersebut. Sehingga jawaban pada butir soal ini salah.

Hal ini diperkuat berdasarkan hasil wawancara, dimana untuk soal nomor 1, responden tidak mengetahui konsep yang digunakan, tidak yakin, dan tidak berani mengerjakan soal karena merasa takut jawabannya salah. Selain itu, ia juga tidak dapat menjelaskan hubungan antara butir soal nomor 1 dan 2. Sedangkan untuk butir soal nomor 3 dan 4, ia salah dalam menuliskan rumus operasi pembagian turunan dan tidak dapat menjelaskan hubungan antara soal nomor 3 dan 4 .

\section{Responden 5 (PD)}
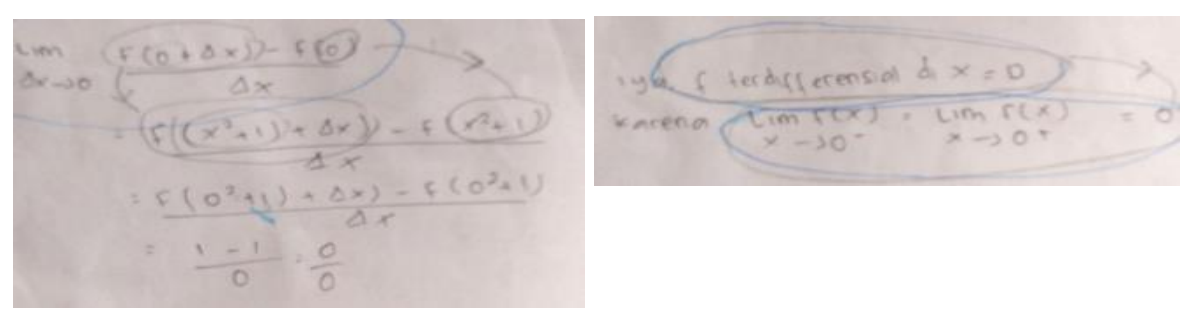

Gambar 6. Jawaban Responden 5 untuk Butir Soal Nomor 1 dan 2 
Berdasarkan gambar 6 jawaban butir soal nomor 1, responden menggunakan konsep limit kiri dan limit kanan. Hanya saja pada proses penghitungan terdapat kesalahan. Ia menuliskan $\lim _{x \rightarrow 0^{+}}=2 x^{2}-x^{2}=0$ yang seharusnya adalah $\lim _{x \rightarrow 0^{+}}=2 x-x^{2}=0$. Setelah itu, ia menggunakan rumus turunan fungsi di titik 0 . Terdapat kesalahan pada proses penggantian fungsi. Ia menuliskan $f(0)=f\left(x^{2}+1\right)$, yang seharusnya adalah $f(0)=0^{2}+1=1$. Selain itu, hasil yang diperoleh dalam bentuk $\frac{0}{0}$ atau dengan kata lain tidak terdefinisi. Untuk butir soal nomor 2, ia menuliskan kesimpulan, yaitu: karena $\lim _{x \rightarrow 0^{+}} f(x)=\lim _{x \rightarrow 0^{-}} f(x=0$, maka $f$ terdifferensial. Kesimpulan tersebut tidak benar karena pada proses menentukan limit kanan juga salah. Selain itu, dalam menentukan limit kiri dan kanan tidak diketahui fungsi $f(x)$ nya. Untuk jawaban butir soal nomor 3, ia menggunakan rumus turunan fungsi pembagian yaitu $y^{\prime}=\frac{u^{\prime}(x) \cdot v(x)-u(x) \cdot v^{\prime}(x)}{(v(x))^{2}}$. Dalam proses menjawab, ia sudah benar dalam menentukan turunan fungsi. Sedangkan, untuk jawaban pada butir soal nomor 4, ia menggunakan aturan yang sama seperti pada butir soal nomor 3.

Berdasarkan hasil wawancara, responden tidak dapat menerapkan definisi turunan fungsi di suatu titik dan merasa tidak yakin dengan jawaban pada butir soal nomor 1. Ia sudah dapat menjelaskan hubungan antara nomor 1 dan 2. Sedangkan, untuk butir soal nomor 3 dan 4, ia dapat menjelaskan konsep yang digunakan untuk menyelesaikan persoalan tersebut.

6. Responden 6 (MS)

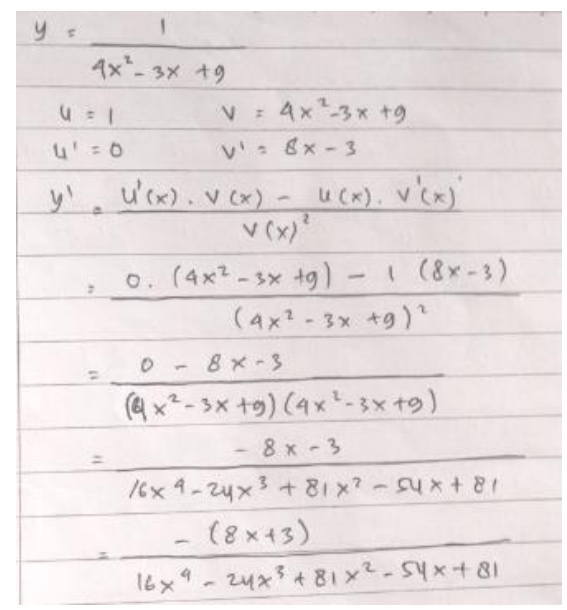

Gambar 7. Jawaban responden 6 untuk soal nomor 3 
Pada jawaban butir soal nomor 1, responden menggunakan konsep limit kiri dan limit kanan dari fungsi $f(x)$ dengan benar. Ia menuliskan definisi turunan fungsi $f$ di titik 0 dan dapat menentukan $f(0)$ dengan benar. Akan tetapi, ia merasa kesulitan untuk menentukan benang merah antara definisi turunan fungsi di titik 0, konsep limit kiri, dan konsep limit kanan. Sehingga, jawabannya masih keliru dan tidak lengkap. Untuk jawaban butir soal nomor 2, ia tidak menjawab dan hanya menuliskan soal saja. Untuk jawaban butir soal nomor 3 seperti pada gambar 7 di atas, ia menuliskan terlebih dahulu fungsi $u(x), v(x), u^{\prime}(x)$, dan $v^{\prime}(x)$. Kemudian menentukan turunan dari suatu fungsi pembagian menggunakan rumus $f(x)=\frac{u^{\prime}(x) \cdot v(x)-u(x) \cdot v^{\prime}(x)}{(v(x))^{2}}$. Berdasarkan jawaban, ia dapat menentukan turunan fungsi pembagian dengan benar. Dan untuk jawaban butir soal nomor 4, ia keliru dalam menentukan turunan fungsi pembagian dan tidak menggunakan aturan turunan untuk fungsi pembagian, tetapi menggunakan aturan langsung sehingga jawaban yang dituliskan menjadi salah.

Berdasarkan hasil wawancara, butir untuk soal nomor 1, ia tidak dapat memahami pertanyaan, tidak mengetahui konsep yang digunakan untuk menjawab persoalan, dan tidak dapat menjelaskan hubungan antara butir soal nomor 1 dan 2. Sedangkan, untuk butir soal nomor 3 dan 4, ia sudah mengetahui konsep yang digunakan dan merasa yakin dengan jawaban nomor 3 dan 4, walaupun pada jawaban butir soal nomor 4 terjadi kesalahan.

7. Responden 7 (FB)

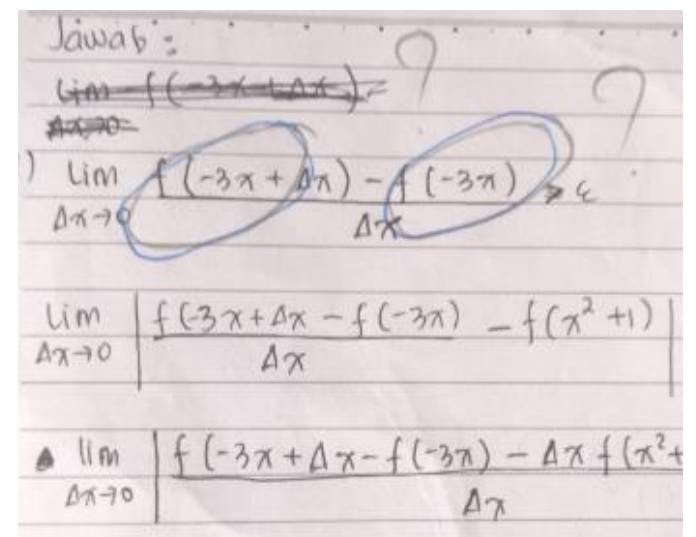

Gambar 8. Jawaban responden 7 untuk butir soal nomor 1

Pada gambar 8, untuk jawaban soal nomor 1, responden menggunakan aturan definisi turunan fungsi di titik 0. Pada bagian pertama terdapat kesalahan. Ia menuliskan $f(3 x+\Delta x)$, 
yang seharusnya $f(0+\Delta x)$. Pada proses penyelesaian, ia kembali mengulangi kesalahan, yaitu menuliskan $f\left(\left(x^{2}+1\right)+\Delta x\right)$. Hal ini berakibat proses selanjutnya menjadi salah. Untuk butir soal nomor 2 , ia menuliskan fungsi $f$ terdifferensial di titik 0 . Untuk jawaban butir soal nomor 3, ia menggunakan aturan invers fungsi, kemudian dicari turunan fungsi menggunakan aturan turunan fungsi pangkat. Jawaban untuk butir soal nomor 3 sudah benar. Dan untuk jawaban butir soal nomor 4, responden menggunakan aturan turunan fungsi implisit. Jawaban yang dituliskan sudah benar. Hal ini berarti, responden sudah dapat menerapkan turunan fungsi parsial dan dapat menentukan struktur soal yang menggunakan turunan fungsi implisit.

Berdasarkan hasil wawancara, responden sudah dapat menuliskan definisi turunan fungsi $f$ di titik 0 , tetapi belum dapat menerapkannya untuk menentukan turunan fungsi. Sebagai contohnya, mahasiswa mengganti angka 0 dengan $3 x$. Seharusnya yang benar adalah 0 , sehingga jawabanya menjadi salah. Ia berpendapat untuk mengerjakan butir soal nomor 2 terlebih dahulu harus mengerjakan butir soal nomor 1 . Artinya jika jawaban nomor 1 salah, maka jawaban nomor 2 juga salah. Pada butir soal nomor 3, ia menggunakan aturan invers. Dan untuk butir soal nomor 4, ia menggunakan aturan turunan fungsi implisit.

\section{Responden $8(\mathrm{OM})$}
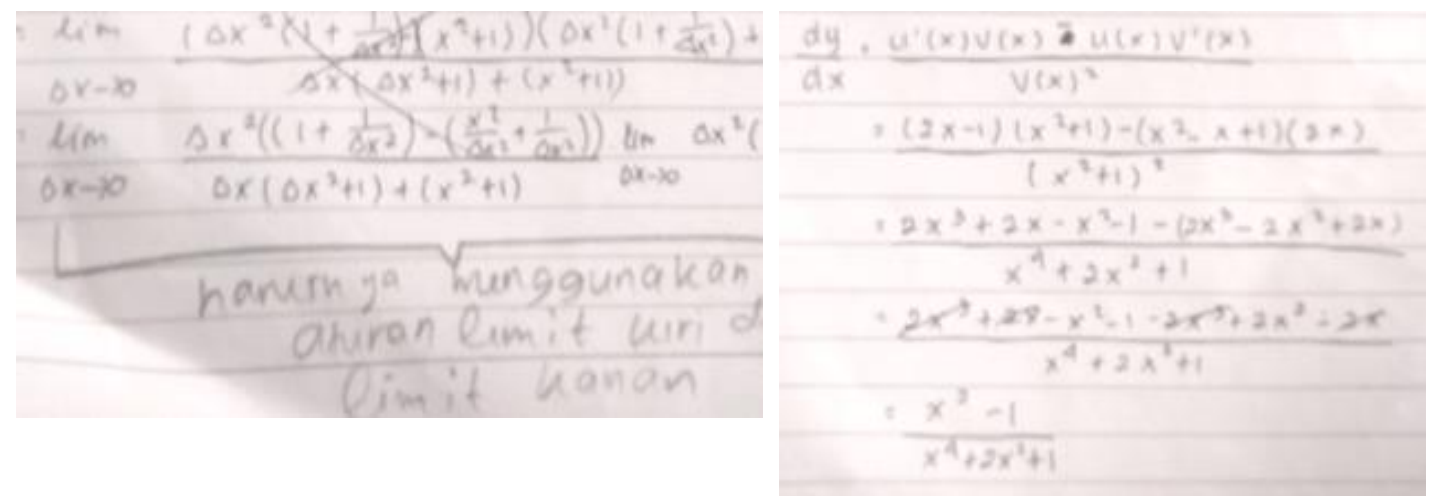

Gambar 9. Jawaban Responden 8 untuk Butir Soal Nomor 1 dan 4

Pada gambar 9, untuk jawaban butir soal nomor 1, responden menggunakan definisi turunan fungsi di titik 0 yaitu $\lim _{\Delta x \rightarrow 0} \frac{f(0+\Delta x)-f(0)}{\Delta x}$. Responden melakukan kesalahan dalam menentukan fungsi $f(0+\Delta x)$. Sehingga, proses selanjutnya menjadi keliru. Untuk jawaban butir soal nomor 2, ia tidak menuliskan jawaban apapun. Untuk butir soal nomor 3, ia menggunakan aturan langsung. Pada bagian penyebut dipindah ke atas dan menempati bagian 
invers atau diinverskan. Kemudian, dikerjakan menggunakan aturan turunan fungsi pangkat yaitu $y^{\prime}=n x^{n-1}$. Berdasarkan jawaban yang dituliskan, responden sudah dapat menentukan turunan fungsi dengan benar. Sedangkan, untuk butir soal nomor 4 terlebih dahulu responden menuliskan fungsi $u(x), v(x), u^{\prime}(x)$, dan $v^{\prime}(x)$, kemudian menggunakan aturan pembagian. Berdasarkan jawabannya, ia sudah dapat menyelesaikan persoalan dengan benar.

Jawaban tersebut diperkuat berdasarkan hasil wawancara. Untuk mengerjakan butir soal nomor 1, ia mengatakan bahwa untuk menyelesaikan butir soal nomor 1 diperlukan konsep definisi turunan fungsi. Jawaban nomor 1 digunakan untuk menjawab nomor 2. Ia juga berpendapat konsep yang digunakan untuk menjawab nomor 1 dan 2 sama yaitu konsep turunan fungsi di suatu titik. Sedangkan untuk menyelesaikan butir soal nomor 3 dan 4 , ia menjelaskan bahwa konsep yang digunakan adalah sifat operasi pembagian turunan.

9. Responden 9 (DS)

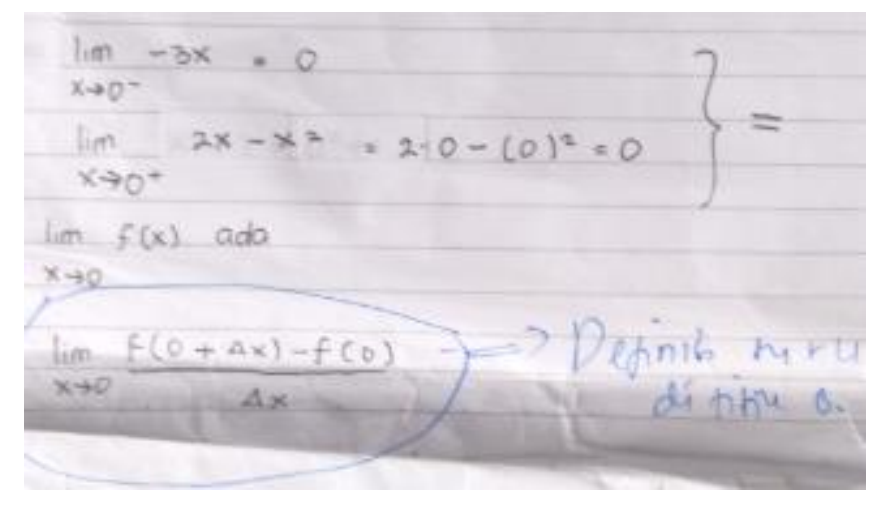

Gambar 10. Jawaban Responden 9 untuk Butir Soal No 1

Berdasarkan jawaban untuk butir soal nomor 1 pada gambar 10 , terlebih dahulu respoden menuliskan limit kiri dan limit kanan. Jawaban yang dituliskan dalam menentukan limit tersebut sudah benar. Kemudian, ia menuliskan kembali definisi turunan fungsi di titik 0 . Dalam menuliskan definisi sudah benar. Hanya saja, ia tidak menuliskan jawaban beserta prosesnya. Sehingga, jawaban yang dituliskan pada nomor 1 menjadi salah. Ia tidak mengerjakan butir soal nomor 2. Untuk jawaban soal nomor 3, ia terlebih dahulu menuliskan fungsi yang dibutuhkan. Ia menggunakan rumus turunan fungsi pembagian. Dan untuk butir soal nomor 4, ia menuliskan kembali fungsi yang dibutuhkan, yaitu $u(x), v(x), u^{\prime}(x)$, $\operatorname{dan} v^{\prime}(x)$, serta menggunakan aturan turunan fungsi pembagian. 
Sedangkan berdasarkan hasil wawancara, untuk butir soal nomor 2, ia hanya menuliskan soal. Ia merasa tidak yakin tentang definisi turunan fungsi $f$ di titik 0 . Untuk butir soal nomor 3 dan 4. responden sudah dapat menjawab soal dengan benar dan mengetahui konsep yang digunakan untuk mengerjakan soal tersebut. Menurut jawaban yang bersangkutan, konsep yang digunakan pada nomor 3 dan 4 adalah sifat pembagian turunan.

Secara singkat penggambaran kemampuan analogi matematis untuk tiap kategori dapat dilihat dalam tabel 2 berikut.

Tabel 2. Kemampuan analogi matematis tiap kategori

\begin{tabular}{ll}
\hline \multicolumn{1}{c}{ Kelompok } & \multicolumn{1}{c}{ Kemampuan Analogi Matematis } \\
\hline Rendah & Mayoritas belum mampu persoalan dengan benar, hal ini diduga karena \\
& ketidakpahaman mereka tentang konsep yang digunakan untuk menyelesaikan \\
& permasalahan. Hal ini terlihat dari ketidakmampuan dalam menyelesaikan butir \\
& soal nomor 1 dan 2. Begitu juga dengan butir soal nomor 3 dan 4, mayoritas \\
& responden salah dalam menggunakan konsep. Ketika konsep pada butir soal \\
& nomor 3 salah, maka berakibat kesalahan konsep pada butir soal nomor 4. \\
& Mayoritas sudah mengetahui kesamaan konsep yang digunakan, akan tetapi \\
& belum mampu mengaplikasikan konsep tersebut untuk menyelesaikan \\
& persoalan sumber dan target. Hal ini ditunjukan beberapa responden sudah \\
& mampu menggunakan aturan pembagian, hanya saja dalam proses \\
& pengerjaannya masih terdapat kekeliruan. \\
& Mayoritas responden sudah mampu mengetahui kesamaan konsep yang \\
& digunakan dan mampu mengaplikasikan konsep tersebut untuk menyelesaikan \\
& persoalan sumber dan target. Atau dengan kata lain kemampuan analogi \\
Tinggi & matematisnya sudah cukup menggembirakan. \\
\hline
\end{tabular}

Berdasarkan hasil tersebut, diperlukan adanya penekanan pada konsep dasar kalkulus serta memerlukan pendekatan terhadap mahasiswa yang termasuk dalam kategori rendah. Mereka membutuhkan pendampingan yang lebih terkait dengan materi pembelajaran dalam hal ini analogi matematis. Sedangkan, untuk kategori tinggi perlu diberikan soal- soal pengayaan yang lebih kompleks sehingga kemampuan analoginya semakin baik. Selain itu, memberikan kesempatan kepada mahasiswa untuk menganalisa masalah dan mengasah kembali kemampuan membandingan dua hal yang memiliki kesamaan konsep. Hal ini didukung oleh penelitian Rahmawati \& Pala (2017), yang menyatakan bahwa kemampuan analogi matematis dapat membantu mahasiswa untuk memahami konsep- konsep matematis.

\section{KESIMPULAN}

Berdasarkan hasil dan pembahasan di atas, dapat disimpulkan bahwa pada kategori rendah mayoritas mahasiswa belum memahami konsep dan keserupaan konsep yang digunakan untuk menyelesaikan persoalan, baik masalah sumber maupun masalah target. 
Pada kategori sedang, mayoritas mahasiswa sudah mampu memahami konsep dan keserupaan konsep yang digunakan, hanya saja belum mampu mengaplikasikannya untuk menyelesaikan persoalan. Sedangkan pada kategori tinggi, mayoritas mahasiswa sudah memahami konsep, keserupaan konsep yang digunakan, dan mampu mengaplikasikannya untuk menyelesaikan masalah sumber dan target.

\section{REFERENSI}

English, L. D. (1993). Reasoning by Analogy in Constructing Mathematical Ideas. U.S.: Educational Resources Information Center (ERIC).

Gentner, D. (2006). Analogical Reasoning, Psychology of. Encyclopedia of Cognitive Science. 106-112. DOI:10.1002/0470018860.s00473

Keane, M. T. (1996). Transfer Between Analogies: How Solving One Analogy Problem Helps to Solve Another. University of Dublin.

Meagher, D. (2006). Understanding Analogies: The Analogy Item Format and the Miller Analogies Test. PsychCorp.com.

Mofidi, S. Et al. (2012). Instruction of Mathematical Concepts Through Analogical Reasoning Skills. Indian Journal of Science and Technology, 5(6).

Rahmawati, D.I. \& Pala, R.H. (2017). Kemampuan Penalaran Analogi dalam Pembelajaran Matematika. Jurnal Euclid, 4(2).

Santrock, J. W. (2008). Psikologi Pendidikan. Jakarta: Penada Media Group.

Shadiq, F. (2009). Kemahiran Matematika. Yogyakarta: Departemen Pendidikan Nasional.

Sudarma, M. (2013). Logika Dasar: Tradisional, Simbolik dan Induktif. Jakarta: Gramedia.

Sugiyono. (2012). Metode Penelitian Kuantitatif, Kualitatif, dan $R \&$ \& . Bandung: Alfabeta.

Suriasumantri, J. S. (1999). Filsafat Ilmu Sebuah Pengantar Populer. Jakarta: Pustaka Sinar Harapan. 